\title{
ORGANIZATIONAL VALUES: ANTECEDENTS OF WELL-BEING AT WORK FOR RURAL SUCCESSORS
}

\author{
PATRICK ZAWADZKI \\ (D) https://orcid.org/0000-0001-9290-3968 \\ SAYONARA F. TESTON ${ }^{1}$ \\ (iD) https://orcid.org/0000-0002-2469-1497 \\ SUZETE A. LIZOTE \\ (iD) https://orcid.org/0000-0002-8702-5096 \\ IEDA M. ORO ${ }^{1}$ \\ (iD) https://orcid.org/0000-0002-2239-531X
}

To cite this paper: Zawadzki, P., Teston, S. F., Lizote, S. A., \& Oro, I. M. (2021). Organizational values: Antecedents of well-being at work for rural successors. Revista de Administração Mackenzie, 23(1), 1-25. doi:10.1590/1678-6971/eRAMG220118

Submission: June 12, 2019. Acceptance: Jan. 22, 2021.

\footnotetext{
1 Western University of Santa Catarina (Unoesc), Chapecó, SC, Brazil.

2 University of Vale do Itajaí (Univali), Biguaçú, SC, Brazil.
}

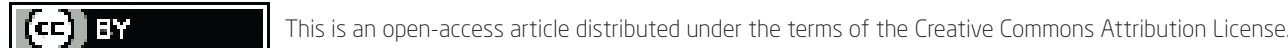

\begin{abstract}
This paper may be copied, distributed, displayed, transmitted or adapted for any purpose, even commercially, if provided, in a clear and explicit way, the name of the journal, the edition, the year and the pages on which the paper was originally published, but not suggesting that RAM endorses paper reuse. This licensing term should be made explicit in cases of reuse or distribution to third parties.

Este artigo pode ser copiado, distribuído, exibido, transmitido ou adaptado para qualquer fim, mesmo que comercial, desde que citados, de forma clara e explícita, o nome da revista, a edição, o ano e as páginas nas quais o artigo foi publicado originalmente, mas sem sugerir que a RAM endosse a reutilização do artigo. Esse termo de licenciamento deve ser explicitado para os casos de reutilização ou distribuição para terceiros.
\end{abstract}




\section{ABSTRACT}

Purpose: This study sought to explore the relationship between wellbeing at work and organizational values in rural properties' successors in a cooperative system.

Originality/value: Empirically, the study presents elements for the strategic management of rural properties, especially for the challenge of preparing successors. For cooperatives, it contributes towards presenting elements for members' management policies and practices. The study also extends the field of studies on well-being at work and the relationship between well-being and values in the organizational environment.

Design/methodology/approach: The method design adopted followed a quantitative approach, with a relational scope, survey type, and crosssectional. Successors representing 119 rural properties in western Santa Catarina participated in the study. Questionnaires assess organizational values and well-being at work as constructs. The descriptive, correlational statistics and structural equations modeling with partial least squares estimation confirm the hypothesis.

Findings: The study's main conclusion suggests that the values of environment dominance and autonomy are associated with commitment, satisfaction, and involvement with work for successors of rural properties in a cooperative system.

\section{KEYWORDS}

Organizational values. Well-being at work. Family successors. Successors. Rural properties. 


\section{INTRODUCTION}

Studies in social and behavioral sciences have the potential to demonstrate which actions can lead to well-being, concerning both individuals and prosperous communities and organizations (Seligman \& Csikszentmihalyi, 2000). For this research, the concept of well-being adopted was the one that considers the positive mental state resulting from satisfaction, involvement, and commitment to work (Siqueira, Orengo, \& Peiró, 2014). In this sense, investigations that explain the relationship between the antecedents of wellbeing are promising, especially for the people management area.

Guest (2017) argues that people management should prioritize the promotion of employee well-being and points out three reasons for this: 1. it is the right thing to think ethically; 2 . external context pressures contain threats; 3. organizations can achieve benefits in terms of both performance and cost savings.

Different factors can be related to well-being. Nielsen et al. (2017), through systematic review and meta-analysis, demonstrated that aspects within the scope of individual, group, leadership, or organizational resources are related to well-being. They add that organizations still need to know more about ensuring that well-being is maintained or promoted among their people (Nielsen et al., 2017).

In the organizational sphere, one of the themes that deserve to be investigated together with well-being, with the potential even to promote it, is the theme of values, especially when it comes to rural successors in a cooperative system (Teston, 2018; Teston, Zawadzki, \& Verdinelli, 2020; Teston, Zawadzki, Lizote, Gupta, \& Reznik, 2020; Zardo, Teston, \& Gupta, 2020). Organizational values have been defined as principles that provide guidance for behaviors and are at the service of an individual, collective or mixed interests (Oliveira \& Tamayo, 2004; Schwartz, 1992).

We opted to investigate these constructs in a research locus with repercussions for regional development: rural properties in a cooperative system. They have a substantial economic and social impact on Brazil and especially on the State of Santa Catarina. According to data from the Empresa de Pesquisa Agropecuária e Extensão Rural de Santa Catarina and Centro de Socioeconomia e Planejamento Agrícola - Epagri/Cepa (2019, p. 7), agriculture in Santa Catarina is formed by " 183,065 agricultural establishments [...], generating about 500 thousand direct jobs and thousands more in different productive chains, generating high added value". Despite this evident economic importance, the problem with this study is the fact that cooperative farms 
face a challenge for their sustainability: the succession process (Boessio \& Doula, 2017; Facioni \& Pereira, 2015; Matte, Spanevello, Lago, \& Andreatta, 2019; Morais, Rech, Binotto, \& Ruviaro, 2016; Ramos, Angnes, \& Costa, 2018; Spavenello, Matte, Andreatta, \& Lago, 2017; Teston \& Filippim, 2016; Teston, Zawadzki, \& Verdinelli, 2020; Teston et al., 2020; Zardo et al., 2020).

In this context, the research's general objective is: To evaluate the relationship between well-being at work and organizational values in rural properties' successors in a cooperative system. A bivariate correlation analysis performs the dimensions of the constructs (organizational values and well-being at work) and, subsequently, a multivariate analysis unravels which dimensions items of each construct presented a relation for the studied sample.

The study contributes to present new evidence to explain the factors that lead to the well-being of successors of rural properties in a cooperative system and their relationship with organizational values. The research also contributes to raising evidence so that both rural properties and the cooperative can adopt policies and practices aligned with the values of their successors to promote the identification, well-being, and, consequently, the sustainability of cooperativism through succession management efficient, a gap already pointed out by Lussier and Sonfield (2012). In the economic and social spheres, the research can contribute to the perspective of the continuity of rural properties in the studied region, which was also demanded by the case cooperative itself. Still, the study aims to contribute to theoretical advances on the evaluation of the relationships between organizational values and well-being, as pointed out by Teston (2018), Teston, Zawadzki, and Verdinelli (2020), and Teston et al. (2020).

\section{THEORETICAL REVIEW}

\subsection{Organizational values}

The starting point of the concept of the organizational values is attributed by some authors (Allison, 2019; Malbašić, Rey, \& Potocan, 2015; Vveinhardt \& Gulbovaite, 2016) to Rokeach's book (1973), in which a value is a belief that a set of behaviors or types of existence is preferable compared to other alternatives. This definition is generalizable both to individual and organizational values, and yet, among the assumptions of existence, social, institutional, and personality determinants are attributed, in which the individual is observed from his actions to know his values. 
For Sagiv, Roccas, Cieciuch, and Schwartz (2017), the values characterize individuals and social groups, such as nations, business organizations, and religious groups. In culture, it is possible to find values that represent goals which group members are encouraged to pursue and serve to justify the search for goals, while at the individual level, values are desirable goals that motivate action and serve as guiding principles in their lives (Kluckhohn, 1951; Schwartz, 1992; Sagiv et al., 2017). It is believed that cultural, organizational, and individual values are complementary and inseparable, influencing whether or not the person will remain a member of a particular group.

Values arise from genetic inheritance and from the impact of exposure to multiple social environments, such as family, educational system, community, and society in general (Sagiv et al., 2017). They are subjective and provide for various attitudes and preferences (Sagiv et al., 2017). They are defined as broad, transitional, and serve as guiding principles for life (Kluckhohn, 1951; Schwartz, 1992; Sagiv et al., 2017). As such, they provide valuable insight into human behavior and the functioning of organizations, concerning the effect of both organizational values on perceived organizational performance and the effect of organizational values on internal stakeholders (Allison, 2019).

In the organizational area, theories point out that the integration between the employee and the work environment must occur through individual adaptation and adjustment to the organization's values (Tamayo, 1996). Based on this motivational similarity, an inventory of organizational value profiles was developed in Brazil (Oliveira \& Tamayo, 2004). In this perspective, organizational values refer to how individuals perceive the values reflected in the work environment. Thus, "values act as integrating elements, in the sense that they are shared by all or most of the organizational members" (Oliveira \& Tamayo, 2004, p. 130). Oliveira and Tamayo (2004) present organizational values as a two-dimensional structure, being collectivist or individualist.

Organizational values have been studied by relating the types of organizational culture and declaration of values as a component of management and strategic communication (Allison, 2019) in their impact on organizational effectiveness (Malbašić, Marimon, \& Mas-Machuca, 2016), such as the structure of competing values is related to the commitment to work (Vuuren, Veldkamp, Jong, \& Seydel, 2007), in the innovation of business models and corporate sustainability (Pedersen, Gwozdz, \& Hvass, 2018), and also as an instrumental way of management and regulating the employee's character related to ethics and well-being dimensions (Jaakson, 2010). 
The studies by Teston (2018), Teston, Zawadzki, and Verdinelli (2020), and Teston et al. (2020) use organizational values from the perspective of Oliveira and Tamayo (2004). Teston (2018) states that these values are related to well-being since feeling good implies making decisions aligned with work values. Teston, Zawadzki, and Verdinelli (2020) studied rural property managers' values and pointed out the importance of studying the topic with successors since thinking about policies and practices aligned with values can contribute to successors identifying themselves and remaining in the countryside. Teston et al. (2020) continued to demonstrate the relationship between individualist and collectivist values and the intention to remain on a rural property. The authors concluded that individualistic values are essential for the decision to stay. Knowing that well-being is an individual nature construct, studying it together with values is vital for advancing theoretical understanding of this audience's subject.

Values evoke feelings, motivate actions towards goals, transcend specific actions and situations and are distinguished from norms and attitudes, guide the selection or evaluation of actions and decisions, are in a priority system characteristic of each individual, and guide everyday actions (Schwartz, 1992). There are links between latent culture and individual values, mediated by social institutions that influence society members' beliefs, values, behaviors, and thinking styles (Schwartz, 2013). Among these institutions, we can point to organizations, in this study, represented by rural properties in a cooperative system.

\subsection{Well-being at work}

In the concept of well-being at work, Siqueira and Padovam (2008) suggest theoretical articulation based on positive psychology propositions and Seligman and Csikszentmihalyi (2000) broaden the understanding of the factors that promote a healthier existence and establishment of links with work and the organization.

There are several studies on the topic of well-being in Brazil. Among them, the work of Hirschle, Gondim, Alberton, and Ferreira (2019, p. 532), in which they state that "the level control of stress in the work environment can help the worker to preserve well-being at work, making better use of their regulatory processes". The study by Santos et al. (2019) demonstrated that it is necessary to promote employees' personal and work development, contributing to the well-being at work of public agents of Brazilian universities.

There are different points of view on the topic of well-being. While in the conception of subjective well-being (Diener, Suh, \& Oishi, 1997), there 
are hedonic principles, in the conception of psychological well-being (Ryff, 1989; Ryff \& Keyes, 1995), there are Eudaimonic principles. For Diener, Suh, Lucas, and Smith (1999), subjective well-being is a cognitive assessment of life satisfaction and predominantly positive emotional experiences to the detriment of negative ones. Psychological well-being refers to the full functioning of a person's potential and considers people's ability to face life's challenges (Keyes, Shmotkin, \& Ryff, 2002). From these perspectives, well-being at work was conceived by Siqueira and Padovam (2008, p. 206) as a "concept integrated by three components: job satisfaction, work involvement, and affective organizational commitment".

The propositions of job satisfaction originate from Hoppock's (1935) concepts and the systematization of Locke (1976). Hoppock (1935) stated that job satisfaction is related to individual emotional and physical satisfaction with organizational environmental factors. Locke (1976) extended this conception and stated that satisfaction refers to a positive emotional state of pleasure resulting from work or work experiences. According to Siqueira et al. (2014), job satisfaction involves a predominantly positive assessment of five dimensions: leadership, colleagues, salary, promotions, and tasks.

The concept of involvement with work (Lodahl \& Kejnar, 1965) received from the authors Siqueira and Padovam (2008) a new conception, aligned with the flow state proposed by Csikszentmihalyi (1999). Any activity can bring a person to a state of flux. There must be a goal through the activity, the individual must overcome the activity's challenges, and there must be feedback (Csikszentmihalyi, 1999).

Mowday, Steers, and Porter (1979) initially defined affective organizational commitment as a strong identification with the organization and a desire to continue working on it. For Siqueira and Padovam (2008), affective organizational commitment arouses positive feelings in the individual, such as enthusiasm, pride, contentment, trust, attachment, and dedication. Thus, satisfaction refers to the bond with the work environment, involvement refers to identifying with the nature of the work performed, and commitment refers to the employer's affective connection (Siqueira et al., 2014).

Based on the propositions about organizational values and well-being at work, the study hypothesis is:

- There is a positive and significant relationship between organizational values and well-being at work for successors to rural properties in a cooperative system. 
The objective pursued in the method established two stages of analysis. The first one consisted of seeking bivariate relationships between the dimensions of the organizational values and well-being at work constructs. The second one evaluated the multivariate relationship between the items of the dimensions of the same instruments.

\section{METHOD}

The cooperative system, the locus of this research, has existed since the 1960s and has branches in Brazil's three southern states and Mato Grosso do Sul (a state in the mid-west region). It operates in the promotion and commercialization of the associates' agricultural production, in the production of seeds, rations, and supplements, in the industrialization of wheat, soy, and corn, and in supermarket chains, agricultural stores, and gas stations. Revenues exceeding BRL 3.7 billion in 2019 demonstrate the economic relevance for Santa Catarina.

The cooperative carried out an annual development program to reduce rural evasion by preparing successors to manage properties. The program consisted of biweekly meetings, with professionals working on topics ranging from developing specific behavioral skills to rural properties' financial management. The complete cycle of the Program lasts approximately one year.

Before the beginning of the program's meetings, the cooperative invites all properties that have potential successors. Subsequently, it holds a meeting with all predecessors (parents) and potential successors, presenting the meetings' objectives and the instruments used (self-report questionnaires, group dynamics, lectures, technical visits, preparation, and project presentation). The participants are the subjects of this research: the successors of rural properties that enrolled in the Program.

Data collection took place during the group's third annual meeting. The research consisted of a census conducted with a quantitative, relational, survey, and transversal approach. After presenting the objective, the information on anonymity and the possibility of quitting the questionnaire were clarified. All participants agreed to participate in the data collection, held in September 2018, during meetings in three municipalities in Santa Catarina. The explanation, application, and collection of the instruments were carried out by a psychologist (Conselho Regional de Psicologia - CRP n ${ }^{\circ} 12 / 05728$ ), who performed a rapport to ensure internal validity of the answers, clarified that the data would be used for research, and guaranteed total anonymity in the data analysis phase. Therefore, as the research is part of the Program, 
with the participants' consent and of those responsible, there was no need to submit to the ethics committee as it represents a minimum risk for the participants (Shaughnessy, Zechmeister, \& Zechmeister, 2007).

The questionnaires were of one hundred and nineteen successors from 119 different rural properties. As the total number of successors to the associated rural properties is unknown to the cooperative and the participants' selection was open to all members, the sampling was unintentional. The G*Power v. 3.1.9.2 defined the sample size (Faul, Erdfelder, Buchner, \& Lang, 2009), applying, a priori, the single coefficient regression test with a fixed model, considering the effect size of $\mathrm{f}^{2}=0.15$, significance level of 0.05 , and the statistical power of 0.95 with only one predictor; the result showed that the required sample would be 89 participants. As the final sample resulted in 119 participants, it is possible to generalize the findings to the population of successors of the cooperative under study.

The constructs were measured using self-administered questionnaires. We opted for the Organizational Values Profile Inventory (Inventário de Perfil de Valores Organizacionais - IPVO) (Oliveira \& Tamayo, 2004), later used by Teston (2018), Teston, Zawadzki, and Verdinelli (2020), and Teston et al. (2020). The Brazilian version of this scale has 48 items distributed in eight dimensions: autonomy, employee well-being, mastery of the environment, prestige, achievement, considered individualistic values, conformity, concern for the collectivity, and tradition, considered collectivist values (Oliveira \& Tamayo, 2004). The definition of each dimension is in Figure 3.1.

\section{(Figure 3.1)}

\section{DEFINITION OF THE IPVO DIMENSIONS}

\begin{tabular}{ll}
\hline \multicolumn{1}{c}{ Dimension } & \multicolumn{1}{c}{ Description } \\
\hline Individualist values & $\begin{array}{l}\text { It brings together items related to the search for constant improvement of } \\
\text { the employee and the organization that expresses itself through } \\
\text { Autonomy (AU) } \\
\end{array}$ \\
& $\begin{array}{l}\text { Indicates the concern of the rural property in providing satisfaction to the } \\
\text { employee, paying attention to the quality of life at work (hedonism). }\end{array}$ \\
\hline $\begin{array}{l}\text { Employee } \\
\text { well-being (EW) }\end{array}$ & $\begin{array}{l}\text { It brings together items related to power, whose central goal is to obtain } \\
\text { status, control over people and resources, as well as to the search for a } \\
\text { environment (DO) }\end{array}$ \\
\hline
\end{tabular}




\section{(Figure 3.1 (conclusion))}

\section{DEFINITION OF THE IPVO DIMENSIONS}

\begin{tabular}{ll}
\hline \multicolumn{1}{c}{ Dimension } & \multicolumn{1}{c}{ Description } \\
\hline Prestige (PR) & $\begin{array}{l}\text { It demonstrates the search for prestige, admiration, and respect for society } \\
\text { because of the quality of its products. }\end{array}$ \\
\hline Achievement (AC) & $\begin{array}{l}\text { It aggregates items that represent values whose central goal is a success. } \\
\text { By demonstrating the competence of the organization and its employees, } \\
\text { it considers the achievement of the goals to be proof of their competence. }\end{array}$ \\
\hline Collectivist values & $\begin{array}{l}\text { It refers to the definition of limits on its members' organizational actions and } \\
\text { behaviors, giving priority to respecting rules and behavioral models, both in } \\
\text { the work environment and in the relationship with other organizations. }\end{array}$ \\
\hline $\begin{array}{l}\text { Conformity (CO) } \\
\text { community (CC) }\end{array}$ & $\begin{array}{l}\text { Composed of values that guide the daily relationship with close individuals } \\
\text { and the community. }\end{array}$ \\
\hline Tradition (TR) & $\begin{array}{l}\text { It contains items related to preservation and respect for customs and } \\
\text { functioning. }\end{array}$ \\
\hline
\end{tabular}

Source: Elaborated by the authors.

According to Oliveira and Tamayo (2004, p. 134), IPVO allows "perspectives to study more adequately the integration of the individual into the organization and to define management strategies centered on the convergence of individual and organizational goals", which is configured as an advantage over other instruments, as it considers that organizational values originate from the personal values of the members of the investigated organization. In the original text of IPVO, the word "organization" was replaced by "rural property" for application successors.

Based on the postulates of Seligman and Csikszentmihalyi (2000), the inventory of well-being at work (IBET-13) validated for Brazil and adopted for this study was by Siqueira et al. (2014). The inventory presents 13 items distributed in two dimensions: commitment and satisfaction, and involvement with work. The definition of each dimension is in Figure 3.2. 


\section{(Figure 3.2)}

DEFINITION OF THE DIMENSIONS OF THE IBET-13

\begin{tabular}{ll}
\multicolumn{1}{c}{ Dimension } & \multicolumn{1}{c}{ Description } \\
$\begin{array}{l}\text { Commitment and } \\
\text { satisfaction (CS) }\end{array}$ & $\begin{array}{l}\text { It refers to positive affective bonds with the organization and also with the } \\
\text { other people with whom it works, income obtained, promotion opportunities, } \\
\text { and tasks to be performed. }\end{array}$ \\
\hline $\begin{array}{l}\text { Involvement with } \\
\text { work (IW) }\end{array}$ & $\begin{array}{l}\text { They are composed of the beliefs that the work done provides pleasant hours } \\
\text { and that important aspects for life are contained therein. }\end{array}$ \\
\hline
\end{tabular}

Source: Elaborated by the authors.

The alternatives of the instruments were answered on a five-point Likert scale, ranging from "totally disagree" (1) to "totally agree" (5), for both IPVO and IBET-13. Initially, the data were organized, coded, and processed using an Excel ${ }^{\circledR}$ spreadsheet and SPSS ${ }^{\circledR}$ software (Statistical Package for the Social Science) version 21 (IBM Corporation, 2012). The correction of the questionnaires followed the authors' guidelines (Oliveira \& Tamayo, 2004; Siqueira et al., 2014). The median of the item's responses calculated the value of the instruments' dimensions, as it is an ordinal variable with a fivepoint scale. The lost data did not exceed $5 \%$ of the sample - the mean of the variable filled in the missing data.

The scales' reliability was verified using Cronbach's alpha ( $\alpha=0.818$ for IBET-13; $\alpha=0.854$ for IPVO). Subsequently, asymmetry ( \pm 2$)$ and kurtosis $( \pm 7)$ determined the near-normal distribution, and the significance level adopted was 0.05 . The data analysis was in two phases. In the first phase, to test the relationship between the constructs' dimensions, Pearson's bivariate $r$ correlation test was applied together with significance tests. In the second phase, the multivariate statistical technique structural equation modeling (SEM) (Hair, Hult, Ringle, \& Sarstedt, 2014), using the Adanco ${ }^{\circledR}$ software version 2.0.1 (Henseler \& Dijkstra, 2015), evaluated the multivariate relationship between the items of the dimensions of the constructs.

\section{RESULTS}

Demographic data were collected on age, sex, and education. The results showed that the participants were between 15 and 33 years old $(\mathrm{m}=22.07$, sd $=4.46)$, with $29(24.4 \%)$ women and $90(75.6 \%)$ men. As for education, 
a person has declared primary education $(0.8 \%), 70(58.8 \%)$ claimed to have completed or incomplete high school, and $22(18.5 \%)$ were in college education or had already completed it. The remaining $26(21.8 \%)$ cases did not declare their education level at the time of data collection. As there was a great heterogeneity in the distribution of these variables, it was decided not to stratify the sample and to exclude these variables from the analysis as control. The investigated rural properties represent a total area of 5471.90 hectares $\left(\mathrm{m}_{\mathrm{d}}=26.5, \mathrm{~m}_{\mathrm{ax}}=1150, \mathrm{~m}_{\mathrm{in}}=3.20\right)$ in Santa Catarina. Participants declared as their first activity milk $(\mathrm{n}=66,55.5 \%)$, farming $(\mathrm{n}=18,15.1 \%)$, pig farming $(\mathrm{n}=14,11.8 \%)$, poultry farming $(\mathrm{n}=13,10.9 \%)$, cattle raising $(\mathrm{n}=7,5.9 \%)$, and horticulture $(\mathrm{n}=1,0.8 \%)$.

In order to analyze the correlation between the dimensions of the constructs, Figure 4.1 presents Pearson's bivariate correlation coefficients (r). The obtained coefficients had their magnitude classified according to Cohen's proposal (1988), in which the values between 0.10 and 0.29 are considered small; between 0.30 and 0.49 are considered average; and between 0.50 and 1 are explained as large.

It appears that involvement with work has a significant correlation at the 0.01 level of small magnitude with environment domain (0.268) and autonomy (0.298). It also has a significant correlation at the level of 0.01 of average magnitude with employee well-being (0.341). Also, it presents significant correlation at the level of 0.05 of small magnitude with prestige (0.202). It is observed that, in the dimension commitment and satisfaction, all significant correlations occur at a level below 0.01 . There is a small magnitude correlation with prestige (0.297) and concern for the community (0.248). Correlations of medium magnitude with realization (0.315) and autonomy (0.442) are verified. Finally, a correlation of great magnitude with employee well-being (0.555). The values of conformity and tradition did not show a significant correlation with any of the well-being at work dimensions.

To test the hypothesis, multivariate analysis of SEM shows the results for the validation of the measurement model and then shows the structural model results. The constructs were considered reflective, independent, and of the first order. Figure 4.2 shows the resulting items with values greater than 0.70 , for both the factor loads and the composite reliability (Fornell \& Larcker, 1981; Hair et al., 2014; Henseler, Ringle, \& Sinkovics, 2009). 


\section{(Figure 4.1)}

\section{CORRELATIONS BETWEEN THE DIMENSIONS OF THE INSTRUMENTS}

\begin{tabular}{|c|c|c|c|c|}
\hline & & & \multicolumn{2}{|c|}{ Well-being at work } \\
\hline & & & $\begin{array}{l}\text { Involvement } \\
\text { with work (ET) }\end{array}$ & $\begin{array}{l}\text { Commitment and } \\
\text { satisfaction (CS) }\end{array}$ \\
\hline \multirow{8}{*}{ 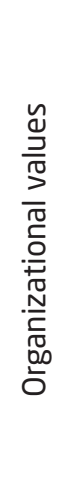 } & \multirow{5}{*}{$\begin{array}{l}\text { Individualist } \\
\text { values }\end{array}$} & Autonomy (AU) & $0.298^{\star \star}$ & $0.442^{\star \star}$ \\
\hline & & Employee well-being (EW) & $0.341^{\star \star}$ & $0.555^{\star \star}$ \\
\hline & & Domain of the environment (DO) & $0.268^{\star \star}$ & 0.144 \\
\hline & & Prestige (PR) & $0.202^{\star}$ & $0.297^{\star \star}$ \\
\hline & & Achievement (AC) & 0.146 & $0.315^{\star \star}$ \\
\hline & \multirow{3}{*}{$\begin{array}{l}\text { Collectivist } \\
\text { values }\end{array}$} & Compliance (CO) & 0.035 & -0.021 \\
\hline & & Concern for the community (CC) & 0.126 & $0.248^{\star \star}$ \\
\hline & & Tradition (TR) & 0.124 & 0.012 \\
\hline
\end{tabular}

** The correlation is significant at the 0.01 level; * the correlation is significant at the level 0.05 .

Source: Elaborated by the authors.

\section{(Figure 4.2)}

FACTOR LOADS AND COMPOSITE RELIABILITY

\begin{tabular}{lcc}
\hline \multicolumn{1}{c}{ Variable } & $\begin{array}{c}\text { Well-being } \\
\text { at work }\end{array}$ & $\begin{array}{c}\text { Organizational } \\
\text { values }\end{array}$ \\
\hline I am happy with the farm where I work (CS). & 0.8176 & \\
\hline I am excited about the property where I work (CS). & 0.7711 & \\
\hline I am satisfied [...] with the interest that my tasks awaken in me (CS). & 0.7112 & \\
\hline I am proud of the property where I work (IW). & 0.7000 & \\
\hline This property seeks to constantly improve (AU). & & 0.7103 \\
\hline For this property, it is important to be creative (AU). & 0.8086 \\
\hline This property stimulates [...] the desire to acquire news (DO). & 0.7349 \\
\hline This property encourages people [...] to be creative (AU). & $0.7417^{*}$ & $0.7541^{*}$ \\
\hline \multicolumn{2}{c}{ Composite reliability (CR) } & \\
\hline
\end{tabular}

* Cronbach's alpha.

Source: Elaborated by the authors. 
Figure 4.3 shows the values obtained for convergent and discriminant validity and the result of the structural path model. Convergent validity was assessed by the average variance extracted (WB AVE $=0.5743$, OV AVE $=$ 0.5647). The Heterotrait-Monotrait correlation ratio demonstrates the discriminant validity $(\mathrm{HTMT}=0.4997)$. The Fornell-Lacker criterion shows that the correlation between the constructs is less than the obtained AVE (diagonal in bold at the top of the table). These two associated criteria demonstrate the model's discriminant validity (Chin, 1998; Henseler et al., 2009; Hair et al., 2014).

\section{(Figure 4.3)}

\section{CONVERGENT VALIDITY, DISCRIMINANT VALIDITY, AND} STRUCTURAL PATH MODEL

\begin{tabular}{cccccccc}
\hline & \multicolumn{3}{c}{ Well-being at work } & \multicolumn{3}{c}{ Organizational values } \\
\hline \multicolumn{3}{c}{ Well-being at work } & \multicolumn{3}{c}{$0.5743^{*}$} & \multicolumn{3}{c}{$0.4997^{\star \star}$} \\
\hline Organizational values & \multicolumn{3}{c}{0.1458} & & $0.5647^{\star}$ & \\
\hline Way & Beta & T-value & P-value & $\mathrm{f}^{2}$ & $\mathrm{R}^{2}$ & $\mathrm{R}^{2}$ aj. & Hypothesis \\
\hline VO ->BET & 0.3818 & 5.4841 & $<0.001$ & 0.1707 & 0.1458 & 0.1385 & Supported \\
\hline
\end{tabular}

** $H T M T$, * AVE, VIF $<1.60$

The bottom part of Figure 4.3 shows the values that support the hypothesis. The relationship between organizational values and well-being at work was significant $(t=5.4841 ; p<0.001)$. Cohen indicator $\left(\mathrm{f}^{2}=\right.$ $0.1707)$ reveals the size of the average effect in the study sample, and the coefficient of determination $\left(\mathrm{R}^{2}=0.1385\right)$ shows the average strength of large correlations effect (Cohen, 1988). The variation inflation factor verified the collinearity between the variables (VIF $=1.5961)$.

\section{DISCUSSION}

The values compliance $\left(\mathrm{r}^{2}=0.035\right.$ and $\left.\mathrm{r}^{2}=-0.021\right)$ and tradition $\left(\mathrm{r}^{2}=\right.$ 0.124 and $\mathrm{r}^{2}=0.012$ ), which are collectivist values, do not show a relationship with the dimensions of well-being at work for successors in the cooperative system. Considering that values evoke feelings when activated, drive action, and serve as standards or criteria that guide actions and decisions 
(Schwartz, 1992), it can be said the there is the possibility of conflict between successors and the cooperative, or even between successors and predecessors. Because of the demand for concern with the maintenance of successors in rural properties and on the cooperative, it is suggested that policies and practices that also aimed at the individualistic values of the successors are adopted (Teston, Zawadzki, \& Verdinelli, 2020; Teston et al., 2020) since, according to Schwartz and Bilsky (1987), it is possible to give priority to different values simultaneously.

Poorly resolved conflicts lead to the successor leaving the property. Consequently, predecessors age in rural areas with no prospect of continuing ownership, the possibility of selling becomes an option, which implies changes in production chains and in the distribution of land areas, that is, it alters productive dynamics (Spavenello et al., 2017; Zardo et al., 2020). Evidence from the study points out how factors that favor the decision to remain on the property are the need for an asset transfer schedule, satisfactory and distributed income to family members, public policies, land purchase, internet access, education, and also to forming a couple with someone who accepts part of the responsibility in the activities of the property (Matte et al., 2019). An empirical contribution points to the need to reorganize families' social lives and their role in the cooperative, using the alignment between well-being at work and organizational values.

There is a concern on the part of the successors with the people management process, especially concerning promoting the well-being of hired employees and/or workers in the property $\left(\mathrm{r}^{2}=0.341^{* *}\right.$ and $\left.\mathrm{r}^{2}=0.555^{* *}\right)$. Some of the investigated rural properties work with temporary hires during the harvest period, others with employees formally hired under the Brazilian juridic regime, and/or members of the owning family. The questions about employee well-being focus on the rural property's concern in providing satisfaction, paying attention to the quality of life at work in the hedonic sense (Oliveira \& Tamayo, 2004; Schwartz, 1992). In this sense, investing in mechanisms to maintain and/or improve the relationship of successors with the people they work with and to improve leadership skills, as successors are preparing to take on rural management, can be a proactive strategy.

Leadership in the rural environment has characteristics evidenced by the organizational culture to which it belongs, subordinates the qualification of managers, collective actions, and power relations are factors that influence the relationship between leaders; and specifically in agricultural cooperatives, evidence points out that the traces of the relationships are personalism, paternalism, spectator posture, mechanisms of personal loyalty 
and avoidance of conflict (Morais et al., 2016). As the culture seems to have striking personal characteristics, migrating to a formal culture to promote property sustainability could be the focus of future research. In this sense, there are proposals for formal succession models, in which the preparation of successors depends on the factors: influences of the founder, multigenerational socialization, demographic aspects, and learning (Teston \& Filippim, 2016).

Continuous improvement of both organizations and individuals is related to work well-being. Mainly, the greater the perception of autonomy $\left(\mathrm{r}^{2}=\right.$ $0.442^{* *}$ ) on the part of the successor, the greater the intensity of the bond with the rural property, that is, the commitment and satisfaction are mainly increased, followed by involvement with work $\left(\mathrm{r} 2=0.298^{* *}\right)$. Schwartz (1992) and Oliveira and Tamayo (2004) interpreted autonomy as a dimension that brings together items related to the search for constant improvement and expressed through competence, curiosity, creativity, variety of experiences, the definition of professional goals, and openness to challenges. Further studies on autonomy with this audience are necessary (Teston et al., 2020), therefore, carrying out activities and proposing challenges to promote the learning of successors in rural properties. The opening of successors to learning and innovation already represents a significant gain for rural property management development.

The openness to development through learning and innovation can lead to formal governance mechanisms that allow the property's sustainability to support the predecessor in his jubilee and the jubilee of sucessor generations of successor generations.

The achievement $\left(\mathrm{r}^{2}=0.315^{* *}\right)$ is associated with the successors' commitment and satisfaction. Achievement is a value that adds items that consider the achievement of goals and objectives as proof of their competence (Oliveira \& Tamayo, 2004; Schwartz, 1992). It indicates that the cooperative and predecessors should be concerned with implementing a professional successor preparation process because successors seek to achieve their goals effectively, and for that, task definitions, roles, goals, processes, and relationships require specialized monitoring.

Records of families who do not wish to remain in a profitable and undeveloped rural environment and who, instead, wish to live with technology, comfort, stability, quality of life, and everything that modern society has to offer, have already been carried out (Boessio \& Doula, 2017). The lifestyle seems to be an essential point for realizing these successors, and it is essential by both the predecessors and the cooperative. In this sense, the prestige value seems to be important because it presents significant correlations with work involvement $\left(\mathrm{r}^{2}=0.202^{*}\right)$ and with commitment and satisfac- 
tion $\left(r^{2}=0.297^{* *}\right)$. For this reason, a professional process of preparation for succession is justified to achieve this alignment. Besides, offering comforts that successors seek in the city in rural areas should be a path.

The successors reported that searching for improvement and creativity, as well as the property's ability to stimulate in the customers the desire to acquire news and the incentive to the creativity of the people who work on the property, are values associated with contentment, excitement, pride, and satisfaction regarding the degree of interest that the tasks arouse in the successor. In this sense, the values of autonomy, employee well-being, and prestige are antecedents of both involvements with work and commitment and satisfaction. The environment domain can be considered a precedent of involvement with work $\left(\mathrm{r}^{2}=0.268^{* *}\right)$ and commitment and satisfaction $\left(\mathrm{r}^{2}=0.315^{* *}\right)$.

Individualist values were more critical for successors than collectivist values in the association with well-being since only concern for the community was related to commitment and satisfaction $\left(\mathrm{r}^{2}=0.248^{* *}\right)$. If there is a perception that the property's central values and the cooperative must be collectivist, this result can be considered negative and, with that, it becomes a source of conflict. However, collectivist and individualistic values are opposed and complementary (Schwartz, 1992). Valuing individualistic values does not mean neglecting collectivist values. It means that the property and the cooperative must adapt, creating policies and practices to meet the successors' individualist values. Finding the congruence between organizational values and behavior, in this case of the successor, seems to be essential to create meaning in life and reduce emotional stress (Chrystal, Karl, \& Fischer, 2019), and it seems to be a key to well-being. Thus, the study contributes theoretically to the studies of Teston (2018), Teston, Zawadzki, and Verdinelli (2020), and Teston et al. (2020), in which it makes sense to measure well-being together with values, and adds that, in the case of the successors investigated, it is the individualistic values that give meaning to well-being at work.

The most significant factor loads of the well-being construct express constant improvement of the constructed property, organizational values, and contentment with work. Learning and organizational climate seem to be essential factors for successors. Regarding this, working to promote learning, knowledge, and developing specific skills seems to work as a motivator for successors. Indeed, it can contribute to the improvement of rural properties and the cooperative. Likewise, carrying out interventions to promote better interpersonal relationships can also be a proactive strategy since several family members, often from different generations, make up rural properties. Some properties also have professionals hired to assist in daily activities. 
Respondents consider the property's ability to stimulate in customers the desire to acquire news shows that successors are concerned with a management dimension that does not always appear in the literature. Yukl (2012) argues that a manager's behavior can be oriented to people, to the task, to change, or to have an external orientation, expressed by concern with customers. For Bianchi, Quishida, and Foroni (2017), this perspective expands the leader management grid's vision, emphasizing the people and production dimensions. The successors seem concerned with the agribusiness industry and not only with their part of the chain. They also seek to go beyond the rural property and to understand who their client is to serve him/her with the news.

It appears that there are more items related to the commitment and satisfaction dimension $(n=3)$ than to involvement with work $(n=1)$. More items related to autonomy $(n=3)$ than to the environment domain $(n=1)$. These results are configured as a managerial contribution, as they allow both the cooperative and the rural property to choose priority items to their management policies and practices. Working with a focus on these specific items can increase successors' identification and promote sustainability for rural and cooperative properties by reducing rural areas' evasion.

On the part of the respondents, the importance attributed to the item autonomy can occur because the cooperative-property system can occur through dependence, that is, personalism, paternalism, spectator posture, mechanisms of personal loyalty, and avoidance conflict (Morais et al., 2016). In this context, the search for autonomy can be an alternative for successors, who seem to seek new forms of cooperative-property relationship. Assessing the possibility of validating an autonomy scale for Brazilians is a critical need, based on these findings.

A combination of genetic inheritance and the impact of exposure to various social environments, such as the family, the educational system, the community, and society in general form the values (Sagiv et al., 2017). Values are subjective and provide for various attitudes and preferences (Sagiv et al., 2017). There are several reasons why successors have dominance and autonomy as predominant values. Promoting them is synonymous with strengthening the bond with the work environment, identification with the nature of the work performed, and affective connection with the property and the cooperative (Siqueira et al., 2014). Thus, the challenge of the succession process seems to require adaptation from the cooperative system and from rural properties, which need to adopt policies and practices with which successors find identification to remain, thus providing their well-being. 


\section{CONCLUSIONS}

This study sought to explore the relationship between organizational values and well-being in rural properties' successors in a cooperative system. Organizational values can be considered as antecedents of well-being at work for successors. Specifically, the values of the environment domain and autonomy are associated with commitment, satisfaction, and involvement with work for most of the intensely investigated successors.

Empirically, the study demonstrates the adaptation need by the property, the predecessors, and the cooperative regarding the incentive to develop the successor's autonomy in order for him/her to remain in the field. Theoretically, the results confirm Guest's (2017) notes about the need to look again at property workers' interests and not just the cooperative's. Besides, considering values as antecedents of well-being also contributes to the advancement of studies carried out by Teston (2018), Teston, Zawadzki, and Verdinelli (2020), and Teston et al. (2020) on the importance of studying the relationship between the central constructs, adding that individualistic values are predictors of well-being at work.

This research has limitations. Different results may emerge in other regions or countries. Therefore, the findings cannot be generalized beyond the studied population. The inherent limitations of working with crosssectional data are also recognized since they may be subject to causal effects. An investigation into the flexibility of predecessors and of the cooperative in face of the need to be open to change and adapt to new contexts can be interesting. Furthermore, because of the theoretical findings, it is suggested to expand studies to investigate the contribution of individualistic values to promoting the common good.

\section{VALORES ORGANIZACIONAIS: ANTECEDENTES DE BEM-ESTAR NO TRABALHO PARA SUCESSORES RURAIS}

\section{RESUMO}

Objetivo: Este estudo buscou explorar a relação entre bem-estar no trabalho e valores organizacionais em sucessores de propriedades rurais em sistema cooperativista. 
Originalidade/valor: Empiricamente, o estudo apresenta elementos para a gestão estratégica de propriedades rurais, especialmente para o desafio da preparação dos sucessores. Para as cooperativas, contribui no sentido de apresentar elementos para políticas e práticas de gestão dos associados. O estudo também estende o campo de estudos sobre o bem-estar no trabalho, bem como sobre a relação entre o constructo do bem-estar e o de valores no ambiente organizacional.

Design/metodologia/abordagem: O desenho do método adotado seguiu abordagem quantitativa, com alcance relacional, do tipo survey e de corte transversal. Participaram do estudo sucessores que representam 119 propriedades rurais do oeste catarinense. Foram utilizados questionários para avaliar os constructos valores organizacionais e bem-estar no trabalho. Por meio de estatística descritiva e correlacional e da modelagem de equações estruturais com estimação por mínimos quadrados parciais, confirmou-se a hipótese do estudo.

Resultados: A principal conclusão do estudo sugere que os valores de domínio do ambiente e autonomia estão associados ao compromisso, à satisfação e ao envolvimento com o trabalho para sucessores de propriedade rurais em sistema cooperativista.

\section{PALAVRAS-CHAVE}

Valores organizacionais. Bem-estar no trabalho. Sucessores familiares. Sucessores. Propriedades rurais.

\section{REFERENCES}

Allison, J. (2019). Values statements. International Journal of Organizational Analysis, 27(3), 666-689. doi:10.1108/ijoa-08-2018-1501

Bianchi, E. M. P. G., Quishida, A., \& Foroni, P. G. (2017). Atuação do líder na gestão estratégica de pessoas: Reflexões, lacunas e oportunidades. Revista de Administração Contemporânea, 21 (1), 41-61. doi:10.1590/1982-7849rac 2017150280

Boessio, A. T., \& Doula, S. M. (2017). Sucessão familiar e cooperativismo agropecuário: Perspectivas de famílias cooperadas em um estudo de caso no Triângulo Mineiro. Desenvolvimento em Questão, 15(40), 433-458. doi:10.21527/2237-6453.2017.40.433-458 
Chin, W. W. (1998). The partial least squares approach for structural equation modeling. In G. A. Marcoulides (Ed.), Methodology for business and management: Modern methods for business research (pp. 295-336). Mahwah, NJ: Lawrence Erlbaum Associates.

Chrystal, M., Karl, J. A., \& Fischer, R. (2019). The complexities of "minding the gap": Perceived discrepancies between values and behavior affect wellbeing. Frontiers in Psychology, 10, 1-15. doi:10.3389/fpsyg.2019.00736

Cohen, J. (1988). Statistical power analysis for the behavioral sciences (2nd ed.). New York: Lawrence Erlbaum Associates.

Csikszentmihalyi, M. (1999). A descoberta do fluxo: A psicologia do envolvimento com a vida cotidiana. Rio de Janeiro: Rocco.

Diener, E., Suh, E. M., Lucas, R. E., \& Smith, H. L. (1999). Subjective wellbeing: Three decades of progress. Psychological Bulletin, 125(2), 276-302. doi:10.1037/0033-2909.125.2.276

Diener, E., Suh, E., \& Oishi, S. (1997). Recent findings on subjective wellbeing. Indian Journal of Clinical Psychology, 24(1), 25-41.

Empresa de Pesquisa Agropecuária e Extensão Rural de Santa Catarina (Epagri), \& Centro de Socioeconomia e Planejamento Agrícola (2019). Sintese anual da agricultura de Santa Catarina 2017-2018. Florianópolis: Epagri, Cepa. Retrieved from http://webdoc.epagri.sc.gov.br/sintese.pdf

Facioni, D., \& Pereira, M. W. G. (2015). Análise dos determinantes da sucessão em assentamento rural no estado de Mato Grosso do Sul. Organizações Rurais \& Agroindustriais, 17(1), 119-136.

Faul, F., Erdfelder, E., Buchner, A., \& Lang, A.-G. (2009). Statistical power analyses using $\mathrm{G}^{*}$ Power 3.1: Tests for correlation and regression analyses. Behavior Research Methods, 41, 1149-1160.

Fornell, C., \& Larcker, D. F. (1981). Evaluating structural equation models with unobservable variables and measurement error. Journal of Marketing Research, 18(1), 39-50. doi:10.2307/3151312

Guest, D. E. (2017). Human resource management and employee wellbeing: Towards a new analytic framework. Human Resource Management Journal, 27(1), 22-38. doi:10.1111/1748-8583.12139

Hair, J. F., Jr., Hult, G. T. M., Ringle, C. M., \& Sarstedt, M. (2014). A primer on partial least squares structural equation modeling (PLS-SEM). London: Sage.

Henseler, J., \& Dijkstra, T. K. (2015). ADANCO 2.0.1. Kleve, Germany: Composite Modeling. 
Henseler, J., Ringle, C., \& Sinkovics, R. (2009). The use of partial least squares path modelling in international marketing. In R. R. Sinkovics \& P. N. Ghauri (Eds.), New challenges to international marketing (pp. 277-319). Bingley, UK: Emerald Group Publishing.

Hirschle, A. L. T., Gondim, S. M. G., Alberton, G. D., \& Ferreira, A. S. M. (2019). Estresse e bem-estar no trabalho: O papel moderador da regulação emocional. Revista Psicologia: Organizações e Trabalho, 19(1), 532-540. doi:10.17652/rpot/2019.1.14774

Hoppock, R. H. (1935). Job satisfaction. New York: Harper and Brothers.

IBM Corporation (2012). SPSS Statistics for Windows, version 21.0. Armonk, NY: IBM Corp.

Jaakson, K. (2010). Management by values: Are some values better than others? Journal of Management Development, 29(9), 795-806. doi:10.1108/ 02621711011072504

Keyes, C. L. M., Shmotkin, D., \& Ryff, C. D. (2002). Optimizing well-being: The empirical encounter of two traditions. Journal of Personality and Social Psychology, 82 (6), 1007-1022. doi:10.1037/0022-3514.82.6.1007

Kluckhohn, C. (1951). Values and value-orientations in the theory of action: An exploration in definition and classification. In T. Parsons \& E. Shils (Eds.), Toward a general theory of action (pp. 388-433). Harvard University Press: Cambridge. doi:10.4159/harvard.9780674863507.c8

Locke, E. A. (1976). The nature and causes of job satisfaction. In M. P. Dunnette (Ed.), Handbook of industrial and organizational psychology (pp. 1294-1349). Chicago: Rand-McNally.

Lodahl, T. M., \& Kejnar, M. (1965). The definition and measurement of job involvement. Journal of Applied Psychology, 49(1), 24-33. doi:10.1037/h00 21692

Lussier, R. N., \& Sonfield, M. C. (2012). Family businesses' succession planning: A seven-country comparison. Journal of Small Business and Enterprise Development, 19(1), 7-19. doi:10.1108/14626001211196370

Malbašić, I., Marimon, F., \& Mas-Machuca, M. (2016). Is it worth having focused values? Management Decision, 54(10), 2370-2392. doi:10.1108/ md-05-2016-0282

Malbašić, I., Rey, C., \& Potocan, V. (2015). Balanced organizational values: From theory to practice. Journal of Business Ethics, 130(2), 437-446. doi:10. 1007/s10551-014-2238-0 
Matte, A., Spanevello, R. M., Lago, A., \& Andreatta, T. (2019). Agricultura e pecuária familiar: (Des)continuidade na reprodução social e na gestão dos negócios. Revista Brasileira de Gestão e Desenvolvimento Regional, 15(1), 19-33.

Morais, M., Rech, L. R., Binotto, E., \& Ruviaro, C. F. (2016). A postura dos associados de uma cooperativa frente aos aspectos culturais relacionados a sucessão. Teoria e Prática em Administração, 6(2), 172-199. doi:10.21714/ 2238-104X2016v6i2-29900

Mowday, R. T., Steers, R. M., \& Porter, L. W. (1979). The measurement of organizational commitment. Journal of Vocational Behavior, 14(2), 224-247. doi:10.1016/0001-8791(79)90072-1

Nielsen, K., Nielsen, M. B., Ogbonnaya, C., Känsälä, M., Saari, E., \& Isaksson, K. (2017). Workplace resources to improve both employee wellbeing and performance: A systematic review and meta-analysis. Work $\mathcal{E}$ Stress, 31 (2), 101-120. doi:10.1080/02678373.2017.1304463

Oliveira, A. F., \& Tamayo, A. (2004). Inventário de perfis de valores organizacionais. Revista de Administração, 39(2), 129-140.

Pedersen, E. R. G., Gwozdz, W., \& Hvass, K. K. (2018). Exploring the relationship between business model innovation, corporate sustainability, and organizational values within the fashion industry. Journal of Business Ethics, 149(2), 267-284.

Ramos, V. S., Angnes, J. S., \& Costa, Z. (2018). O futuro da fumicultura: O jovem rural e o dilema da sucessão geracional. Desenvolvimento em Questão, 16(43), 548-572. doi:10.21527/2237-6453.2018.43.548-572

Rokeach, M. (1973). The nature of human values. New York: Free Press.

Ryff, C. D. (1989). Happiness is everything, or is it? Explorations on the meaning of psychological well-being. Journal of Personality and Social Psychology, 57(6), 1069-1081. doi:10.1037/0022-3514.57.6.1069

Ryff, C. D., \& Keyes, C. L. M. (1995). The structure of psychological wellbeing revisited. Journal of Personality and Social Psychology, 69(4), 719-727. doi:10.1037/0022-3514.69.4.719

Sagiv, L., Roccas, S., Cieciuch, J., \& Schwartz, S. H. (2017). Personal values in human life. Nature Human Behaviour, 1(9), 630-639. doi:10.1038/ s41562-017-0185-3

Santos, S. V. M., Robazzi, M. L. C. C., Dalri, R. C. M. B., Bardaquim, V. A., Xavier, J. J. S., Silva, L. A., Freita, F. C. T., \& Vichnewski, E. M. (2019). Bem-estar no ambiente de trabalho em escolas de enfermagem brasileiras. Revista Ciencia y Cuidado, 16(2), 8-20. doi: 10.22463/issn.1794-9831 
Schwartz, S. H. (1992). Universals in the content and structure of values: Theoretical advances and empirical tests in 20 countries. Advances in Experimental Social Psychology, 25, 1-65.

Schwartz, S. H. (2013). Rethinking the concept and measurement of societal culture in light of empirical findings. Journal of Cross-Cultural Psychology, 45(1), 5-13. doi:10.1177/0022022113490830

Schwartz, S. H., \& Bilsky, W. (1987). Toward a universal structure of human values. Journal of Personality and Social Psychology, 53(3), 550-562.

Seligman, M. E. P., \& Csikszentmihalyi, M. (2000). Positive psychology: An introduction. American Psychologist, 55(1), 5-14. doi:10.1037/0003066X.55.1.5

Shaughnessy, J. J., Zechmeister, E. B., \& Zechmeister, J. S. (2007). Métodos de investigación en psicología (7a ed.). México: McGraw-Hill Interamericana.

Siqueira, M. M. M., Orengo, V., \& Peiró, J. M. (2014). Bem-estar no trabalho. In M. M. M. Siqueira (Ed.), Novas medidas do comportamento organizacional (pp. 39-51). Porto Alegre: Artmed.

Siqueira, M. M. M., \& Padovam, V. A. R., (2008). Bases teóricas de bem-estar subjetivo, bem-estar psicológico e bem-estar no trabalho. Psicologia: Teoria e Pesquisa, 24(2), 201-209. doi:10.1590/S0102-37722008000200010

Spavenello, R. M., Matte, A., Andreatta, T., \& Lago, A. (2017). A problemática do envelhecimento no meio rural sob a ótica dos agricultores familiares sem sucessores. Desenvolvimento em Questão, 15(40), 348-372. doi:10.215 27/2237-6453.2017.40.348-372

Tamayo, A. (1996). Valores organizacionais. In A. Tamayo, J. E. Borges-Andrade, \& W. Codo (Eds.), Trabalho, organizações e cultura (pp. 175-493). São Paulo: Cooperativa de Autores Associados.

Teston, S. de F. (2018). Bem-estar psicológico, valores e desempenho de propriedades rurais em sistema cooperativista (Tese de doutorado, Universidade do Vale do Itajaí, Biguaçu, SC, Brasil).

Teston, S. de F., \& Filippim, E. S. (2016). Perspectivas e desafios da preparação de sucessores para empresas familiares. Revista de Administração Contemporânea, 20(5), 524-545. doi:10.1590/1982-7849rac2016150033

Teston, S. de F., Zawadzki, P., Lizote, S. A., Gupta, S. K., \& Reznik, N. (2020). Valores organizacionais percebidos por sucessores de propriedades rurais em sistema cooperativista: Coletivistas ou individualistas? Contextus Revista Contemporânea de Economia e Gestão, 18, 251-263. doi:10.19094/ contextus.2020.44354 
Teston, S. de F., Zawadzki, P., \& Verdinelli, M. A. (2020). Organizational values of rural managers in a cooperative system. Revista de Administração UFSM, 13, 1495-1509.

Vuuren, M. van, Veldkamp, B. P., Jong, M. D. T. de, \& Seydel, E. R. (2007). Why work? Personnel Review, 37(1), 47-65. doi:10.1108/004834808108 39969

Vveinhardt, J., \& Gulbovaite, E. (2016). Expert evaluation of diagnostic instrument for personal and organizational value congruence. Journal of Business Ethics, 136(3), 481-501. doi:10.1007/s10551-014-2527-7

Yukl, G. (2012). Effective leadership behavior: What we know and what questions need more attention. Academy of Management Perspectives, 26(4), 66-85. doi:10.5465/amp.2012.0088

Zardo, D. J., Teston, S. F., \& Gupta, S. K. (2020). Evasion of possible rural successors: Parents and son's perspective. Journal of University of Shanghai for Science and Technology, 22 (10), 2236-2245.

\section{AUTHOR NOTES}

Patrick Zawadzki, master from the Postgraduate Program in Human Movement Sciences, State University of Santa Catarina (Unoesc); Sayonara F. Teston, Ph.D. from the Graduate Program in Administration, University of Vale do Itajaí (Univali); Suzete A. Lizote, Ph.D. from the Postgraduate Program in Administration and Tourism, Univali; Ieda M. Oro, Ph.D. from the Graduate Program in Accounting and Administration, Regional University of Blumenau (Furb).

Patrick Zawadzki is now a professor at the graduation in Physical Education of Unoesc; Sayonara F. Teston is now a professor at the Professional Master in Professional Administration and Doctorate in Academic Administration of Unoesc; Suzete A. Lizote is now a professor at the Postgraduate Program in Administration of Univali; Ieda M. Oro is now a professor at the Master in Professional Administration and Doctorate in Academic Administration of Unoesc.

Correspondence concerning this article should be addressed to Sayonara F. Teston, Avenida Nereu Ramos, 3777-D, Seminário, Chapecó, Santa Catarina, Brazil, CEP 89813-000.

E-mail: sayonara.teston@unoesc.edu.br

\section{EDITORIAL BOARD}

Editor-in-chief

Gilberto Perez

Associate editors

Gardênia da Silva Abbad and

Gilberto Perez

Technical support

Vitória Batista Santos Silva

\section{EDITORIAL PRODUCTION}

Publishing coordination

Jéssica Dametta

Language editor

Daniel de Almeida Leão

Layout designer

Emap

Graphic designer

Libro 